\title{
Contents of Volume 9 (1989)
}

\author{
Number 1. 1989
}

Bormann, E. J.: The Biotechnological Relevance of Regulation of Microbial Secondary Metabolism (in German) . . . . . . . . . . . . . . . . . . . . . . . .

Prabharaksa, Ch.; Olek, A. C.; Steinkraus, K. H.: Enrichment of Soybean Milk with Calcium . . . . . . . . . . . . . . . . . . . . . . . . . . . . .

Riofter, K.: A Reduced Specific Ethanol-Forming Perfomance of Yeast at High Biomass Concentrations as a Result of a Changed Ethanol-Tolerance Behaviour of the Cells under Condition of Limitation. I. A Theoretical Treatment. . . . . . . . . . . . . . . . . .

Richter, K.; Bedker, U.; Meyer, D.: A Reduced Specific Ethanol-Forming Performance of Yeast at High Biomass Concentrations as a Result of a Changed Ethanol-Tolerance Behaviour of the Cells on Condition of Limitation. II. Proving the Effect on High-Flow Rate Fermentations with Saccharomyces cerevisiae Sc 5 . . . . . . . . . . . . . . . . . . . . .

Czajkowska, D.; Ilnicka-Olejniczak, O.: Biosynthesis of Protein by Microscopic Fungi in Solid State Fermentation. II. Optimization of Aspergillus oryzae A. or. 11 Cultivation for Protein Enrichment of Starchy Raw Materials . . . . . . . . . . . . . . . . . . . .

KuschK, P.; Kevbrin, V. V.: Fed-Batch Cultivation of Methanobacterium formicicum and its Fluorometric Monitoring . . . . . . . . . . . . . . . . . . . . . . . .

Maliszewska, I.; Sroka, Z.: The Effect of Culture Conditions on Proteolytic Productivity of Lipolytic Microorganisms . . . . . . . . . . . . . . . . . . . . . . . . . . .

Marfn-InIesta, F.: New Method for the Characterization of the Microbial Growth in Carrageenan Gel . . . . . . . . . . . . . . . . . . . . . . . . . . . . . . . .

Sen, S. K.; Chatterjee, S. P.: Influence of B-Vitamins and Trace Elements on Lysine Production by Micrococcus varians $2 \mathrm{Fa}$. . . . . . . . . . . . . . . . . . . . . . .

Gey, M.; ThIem, M.; Gruel, H.: Characterization of Biotechnological Processes and Products Using High-Performance Liquid Chromatography (HPLC) IV. SEC, HIC, and IEC Separations of Proteins . . . . . . . . . . . . . . . . . . . . . . . . .

Rogalski, J.; Dawidowrcz, A.; Kapusta, K.; Mredziak, I.; Leonowicz, A.: The Application of New Aminoorganic Silanes for Affinity Chromatography of Plant Peroxidase on Vanillin-Liganded Controlled Porosity Glass Columns . . . . . . . . . . . . . . . . .

Müller, S.; Schmid, A.: Flow Cytometric Determination of Yeast Sterol Content . . . . 89

\section{Number 2. 1989}

Sukara, E.; Doelle, H. W.: Optimization of Single Cell Protein Production from Cassava Starch (Rhizopus oligosporus) . . . . . . . . . . . . . . . . . . . . . . . . . . . . 99

WARnecke, H.-J.: Macromixing Characteristics of Gas-Liquid Jet Loop Reactor . . . . . 111

Richter, K.; RÜhlemane, I.; BeCker, U.; Berger, R.: A Comparison between the Fermentative Activities of Free and Ca-Alginate-Entrapped Cells of Saccharomyces cerevisiae. .

Schneider, J. D.; Hadeball, W.; Femler, E.: Continuous Fermentation of Methanol and in Mixtures with Grain of Stillage and Molasses with Hansenula polymorpha MH 26 (in German) . . . . . . . . . . . . . . . . . . . . . . . . . . 131

Onaghise, E. O.; IzdagBe, Y. S.: Improved Brewing and Preservation of Pito, a Nigerian Alcoholic Beverage from Maize. . . . . . . . . . . . . . . . . . . . . . 137 
Madan, M.; KAMra, N.: Comparative Organic Growth Factor Requirements of Nine Candida species. . . . . . . . . . . . . . . . . . . . . . . . 143

Styogantseva, J. M.; Are, R. J.; Viesturs, U. E.: Growth of Pellets of a Basidal Fungus Pleurotus ostreatus under Various Cultivation Condition

Hartung, B.: Streptomycetes as Producers of Industrial and Diagnostic Important Enzymes (in German)

Sовоткоví, L. ; Sik yтA, B.; SmékaL, F.: Production of Lysine by Mutants of Escherichia coli $\mathrm{K} 12$ in a Medium with Lactose . . . . . . . . . . . . . . . . . . . . . . . . . . 173 173

Witte, K.; Wartenberg, A.: Purification and Properties of two $\beta$-Glucosidases Isolated from Aspergillus niger . . . . . . . . . . . . . . . . . . . . . . . . . . . . . . . 179

Spasov, S.; Bakalova, N.; Kolev, D.; Nikolov, T.: Immobilization of Cellulase Complex on a Soluble Polymer (in Russian) . . . . . . . . . . . . . . . . . . . . . . . . . 191

Riedel, K.; Huber, H.; KÜHN, M.: Storage of Microorganisms in Polyvinylalcohol (in German) . . . . . . . . . . . . . . . . . . . 197 197

\section{Number 3. 1989}

OKтYabrsky, O. N.; Smirnova, G. V.: Dynamics of Redox Potential in Bacterial Cultures Growing on Media Containing Different Sources of Carbon, Energy and Nitrogen . . . . . 203

Pelechovâ, J.; Kulhánek, M.; Gramanová, I.; KreJč́, J.; Heřmánková, V.; Staněr, J. jr.: Characterization of the Course of D-Glucitol Biotransformation by Strains Gluconobacter oxydans . . . . . . . . . . . . . . . . . . . . . . . 2

Sohröder, R.; Engel, J.; ChIstoserdov, A. Y.; Tsygankov, Y. D.: Construction of a Promoter-Probe Vector for the Methanol-Utilizing Bacterium Acetobacter methanolicus MB 58. . . . . . . . . . . . . . . . . . . . . . . . . . . . . . 219

KostkA, G.; KAczkowski, J.: Oxygen Requirements of Aspergillus awamori Fungi in the Process of Glucoamylase Biosynthesis . . . . . . . . . . . . . . . . . . . . . . . . 227

Dalev, P.: Protein Isolate and Other Fractions for Human Consumption from the SmallValue Fish Species Black Sea Minnow (Spratus Spratus Phalericus) . . . . . . . . . . . 233

Łobarzewski, J.; WoJcrk, A.; Braszczynska, T.: Immobilization of Enzymes on Porous Silica Supports . . . . . . . . . . . . . . . . . . . . . 239

ISKE, U.; HüBNER, K.: Possibilities for Increasing the Heavy-Metal-Sorption Capacity of Microorganisms (in German) . . . . . . . . . . . . . . . . . . . . . 247

Buisman, C.; Post, R.; IJspeert, P.; Geraats, G.; Lettinga, G.: Biotechnological Process for Sulphide Removal with Sulphur Reclamation . . . . . . . . . . . . . . . . . . . 255

SAFA

Rogalski, J.; Dawidowicz, A. L.: Controlled Porous Glass (CPG) with Reactive Epoxy Groups as Support for Affinity Chromatography. I. Optimization of CPG Modification and the Binding of Glucose with Modified Surface . . . . . . . . . . . . . 275

Weichert, D.; Klappach, G.; Schröter, H.: Application of $\mathrm{pO}_{2}$-Electrode for DissolvedOxygen Determination in Organic Liquids (in German) . . . . . . . . . . . . . . . 285

PlachÝ, J.: Lysine Production by Auxotrophic-Regulatory Mutants of Corynebacterium glutamicum . . . . . . . . . . . . . . . . . . . . . . . . . 291

Nada, A. M. A.; El-Drwany, A. I.; Elshafet, A. M.: Infrared and Antimicrobial Studies on Different Lignins . . . . . . . . . . . . . . . . . . . . . . . . . . . . 295 


\section{Number 4. 1989}

Sangodkar, U. M. X.; AldrioH, T. L.; HaUgland, R. A.; Johnson, J.; Rothmel, R. K.; Chapman, P. J.; Chakrabarty, A. M. : Molecular Basis of Biodegradation of Chloroaromatic Compounds . . . . . . . . . . . . . . . . . . . . . . . . . 301

Czajkowska, D.; Ilnicka-Olejniczak, O.: Biosynthesis of Protein by Microscopic Fungi in Solid State Fermentation. III. The Effect of Different Cultivation Methods and Various Media on Protein Biosynthesis by Aspergillus oryzae A. or. 11 . . . . . . . . . . . . 317

Jinescu, G.; Lavric, V.; BrăgǍrea, St.; Popescu, M.: Mathematical Modelling of Immobilized Living Yeast Cell Reactor for Sugar Bioconversion to Ethanol . . . . . . . . . . . 325

Gräre, U.: New Knowledge about Regulation of Secondary Metabolism in Streptomycetes (in German) . . . . . . . . . . . . . . . . . . . . . . . . . . 333

EL-Diwany, A. I.; Hamdy, A. H. A.; Farid, M. A.: Optimization of Some Culture Parameters and Properties of $\beta$-Glucosidase and $\beta$-Xylosidase from Penicillium funiculosum NRRL-13033

FIedUREK, J.; ILCZUK, Z.; Łobarzewski, J.: Influence of the Mycelium Growth Conditions on the Production of Amylolytic, Proteolytic and Pectinolytic Enzymes by Aspergillus niger C 355

Van Huynh, N.; Van den Cruys, K.; Van Roey, G.; Decleire, M. : Comparative Determination of the Rates of Kluyveromyces bulgaricus Protoplast Formation by the Coulter Counter Technique and Spectrometry . . . . . . . . . . . . . . . . . . 363

Macholan, L.; FLf́pek, J.; Andrýs, C.: Assays Urea and Arginase with a Biocatalytic Membrane Electrode Operating on Conductimetric principle . . . . . . . . . . . . . . 369

Veljkovié, V. B.; Lazíc, M. L.; Rutío, D. J.; Stanković, M. Z.: The Effects of some Inorganic Salts on the Ethanol Fermentation of Juniper Berry Sugars . . . . . . . . . . . 379

BAYER, C.; NAGEL, B.: UV/VIS Diffuse Reflectance and Fluorescence Spectroscopy of Glucose Fermentation with Saccharomyces cerevisiae . . . . . . . . . . . . . . . . . 383

Igina, E. F.; Tulemisova, K. A.; Nikitina. E. T.: Productivity of Cultures from Secondary Colonies of Streptomycetes Producing Anthracycline Antibiotics . . . . . . . . . . . . 389

\section{Number 5. 1989}

WÜNSOHE, L.: Importance of Bacteriophages in Fermentation Processes . . . . . . . . . 395

Letre, M.; Apine, A.; Zeltina, M.; Shvinka, J.: Energetic Efficiency of Complex Substrate Utilization by Trichoderma viride . . . . . . . . . . . . . . . . . . . . . . . .421

RIOHTER, K.; Becker, U.: Effects of Temperature on Microbial Ethanol Production. IV. The Influence of Ethanol on the Temperature-Profile Curve of Ethanol Production . . . . . . 43

Petryaev, E. V.; Vetrov, V.S.; Pavlov, A. V.; Stakhegv, I. V.; Babitskaya, V. G.; Gorbachev, V. M.; GlushonoK, T. G.: Irradiation Treatment of Straw for its Microbiological Conversion - A Method for Production of Feed Protein . . . . . . . . . . . . . 441

Uszycka-Horawa, T.; Skibińska, M.; Jakubowski, W.: New Synthetic Route to 9 $\alpha$ Hydroxy-4-androsten-3,17-dione . . . . . . . . . . . . . . . . . . . . . 44

Drozdov-Tikhomirov, L N.; Grizhebovskaya, A. T.; Min'ko, E. C.: Simulation of a Bacterial Population Structure in Continuous Cultivation by a Dissociation Process: An Application to Rhodococcus rubropertinctus . . . . . . . . . . . . . . . . . . . . . . . . 453

Hommel, R.; Götzrath, M.; Kreber, H.-P.: Enzyme Production by Growing Cells of Acinetobacter in Presence of Sophoroselipid and Triton X-100 . . . . . . . . . . . . 461 
Rucka, M.; Sroka, Z.: Hollow Fiber Modules as a Tool for Enzyme and Cell Immobilization 467

HÜBNER, K.; Iske, U.: Influence of Cultivation Conditions of Microorganisms on their Sorption of Metals (in German) . . . . . . . . . . . . . . . 473

Elshafer, A. M.: Degradation of L-Arabonate by Extracts of Different Filamentous Fungi 479

Elshafer, A. M.: Degradation of Some Sugars and Sugar Acids by the Nonphosphorylated D-Gluconate Pathway in Aspergillus ustus . . . . . . . . . . . . . . . . . . . 485

Gey, M.; Thiersch, A.; Rietzschel, A.; Nattermüller, W.; Stottmeister, U.; Nagel, B.: Characterization of Biotechnological Processes and Products Using High-Performance Liquid Chromatography (HPLC). V. Analysis of Organic Acids in the 2-Oxo-D-gluconic Acid Synthesis .

\section{Number 6. 1989}

Iske, U.; SCHÖN, G.; JECHOREK, M.; Rost, H.-J.: Apparatus System for Control in Fermentation Processes Using Mass Spectrometry (in German) . . . . . . . . . . . . . . 499

Kopp, TH.: Bubble-Free Aeration (in German) . . . . . . . . . . . . . . . . . 504

Thalmann, E.: Biological Experiences in a Bubble-Free Aeration System (in German) . . 511

PöHland, D.; Klappach, G.; HÜHN, J.; SchuRig, K.-H. : Engineering Analysis for Maximum Possible Productivity of Microbial Upper Limits (in German) . . . . . . . . . . 517

Grosse, H. H.; Hitliger, M.; Bormann, E.-J.: Process Control of Dissolved Oxygen Level in Aerobic Microbial Fermentations (in German) . . . . . . . . . . . . . 522

Goldschmidt, B.; Lindner, U.; Mathiszik, B.; Tiller, V.: Modelbase Biotechnology - a Software Package for Selection of Models, Optimization, and Simulation of Biotechnological Processes (in German).

Liebs, P.; Riedel, K.; Pfeiffer, D.; Zimare, U.; Lietz, P.; Scheller, F.: Biosensor Application in Food Industry (in German) . . . . . . . . . . . . . . 534

Geppert, G.; Thelemann, H.; LANGKopf, G.: Industrial Instruments for Determination of Turbidity in Liquid Media (in German) . . . . . . . . . . . . . . . . . . . 541

Geppert, G.; Hanschmann, G.; Threlemann, H.: Quasicontinuous Determination of Alcoholic Concentration in Fermentation Media (in German) . . . . . . . . . . . 545

Dobreva, E.; Ivanova, V.: Characterization of Products of the Starch Hydrolysis Obtained after Action of a Thermostable $\alpha$-Amylase (in German) . . . . . . . . . . . . . . . 549

SzczodraK, J.: Simultaneous Saccharification and Fermentation of Cellulose: Effect of Ethanol and Cellulases on Particular Stages . . . . . . . . . . . 555

Ruklisha, M. P.; Vanags, J. J.; Rikmanis, M. A.; Toma, M. K.; Viesturs, U. E.: Biochemical Reactions of Brevibacterium flavum Depending on Medium Stirring Intensity and Flow Structure . . . . . . . . . . . . . . . . . . . . 565

Acta Biotechnologica is indexed or abstracted in Current Contents/ET \& AT;

Chemical Abstracts; Biological Abstracts; Biotechnology Abstracts; Excerpta Medica 